\title{
MAIN SULPHUR CONTENT IN ESSENTIAL OIL OF ERUCA SATIVA AS AFFECTED BY NANO IRON AND NANO ZINC MIXED WITH ORGANIC MANURE
}

\author{
ABDEL WAHAB M. MAHMOUD*and SAHAR S. TAHA \\ Cairo University, Giza, Egypt
}

MAHMOUD, A.W.M. - TAHA, S.: Main sulphur content in essential oil of Eruca sativa as affected by nano iron and nano zinc mixed with organic manure. Ariculture (Pol’nohospodárstvo), vol. 64, 2018, no. 2, pp. 65-79.

Profitable prospective of rocket plant is progressively growing recently. Hence an experiment was conducted in open field to evaluate the effect of chicken manure, nano iron (Fe), nano zinc ( $\mathrm{Zn})$ and combination of them on morphological, fresh weight and seed yield, photosynthetic rate, transpiration rate, water use efficiency and chemicals constituents represented in macro and micro elements, plant pigments, total phenolics, total carbohydrate, alkaloids, tannins, flavonoids, ascorbic acid, crude protein, total fatty acids, indole acetic acid (IAA) and abscisic acid (ABA) hormones, oil seed yield and methylthiobutyl-isothiocyanate as main sulphur content in essential oil of Eruca sativa Mill. compared to chemical fertilisers (NPK) as control. Results revealed that, nano Fe and $\mathrm{Zn}$ treatments either alone or in combination with manure had the upper hand, where significantly increased almost all parameters under study in comparison with control. The outcomes of present research gave emphasis to global warning about pollution of chemical fertilisers and safety production.

Key words: chemicals constituents, nano Fe and Zn, oil yield, photosynthetic rate, rocket plant

Rocket salad (Eruca sativa Mill.) is a well known fresh vegetable that belonged to the Brassica family. The consumption of vegetables as fresh salad has been increased worldwide because of the health consciousness. In Egypt, about 5,000 fadden (one fadden equal $4,200 \mathrm{~m}^{2}$ ) are cultivated with rocket plants (FAO 2000). Leaves of rocket are mainly used as an astringent, antiphlogistic, diuretic, tonic, depurative, emollient, laxative, digestive, stimulant, and rubefacient (Yaniv et al. 1998). Besides its importance as green salad available all over the year, rocket seeds contain oil which is promising to be medical oil (Khoobchandani et al. 2010). Similar to other Brassica crops, rocket salad is known for various phytochemical metabolites such as polyphenols, vitamin C (Kim et al. 2006; Martınez-Ballestra et al. 2008). It is rich in iron, potassium and sulfur also contains elevated levels of proteins and vitamins A (Porto et al. 2013).

Chemical fertilisation has met with success only in some situations, and negative effects of chemical fertilisers application such as a high probability of leaching, spray drift (wind), volatilization, and high energy consumption for their creation, the risk of toxic build up of chemicals such as arsenic, cadmium, and uranium in the soil. Long-term use of chemical fertiliser can change the soil $\mathrm{pH}$, hurt helpful microbial ecosystems, enhance pests, stimulation of the vegetative growth and reduction of soil water storage on plant growth in semi-arid region have been reported (Rai et al. 2015).

Several reports state the possibility of improving nutritional quality, polyphenols, antioxidants, anthocyanins, vitamins, and minerals in vegetables

Abdel Wahab M. Mahmoud (*Corresponding author), Plant Botany Department, Plant Physiology division, Faculty of Agriculture,Cairo University, El-Gama St. 9, 12613 Giza, Egypt.E-mail: Mohamed.mahmoud@agr.cu.edu.eg; mohamedabdelwahab@cu.edu.eg

Sahar S. Taha, Vegetable Crops Department, Faculty of Agriculture, Cairo University, El-Gama St. 9, 12613 Giza, Egypt 
by the organic fertilisers (Peck et al. 2006). Among agronomical practices, the advantages of the utilization of organic manure for improving the physicochemical properties of soil have been documented (Rudrappa et al. 2006). Numerous researchers showed the importance of manure on increasing crop production. Manure is loaded in nutrients and can provide all macronutrients $(\mathrm{N}, \mathrm{P}, \mathrm{K}, \mathrm{Ca}, \mathrm{Mg}$ and $\mathrm{S})$ essential for plant growth, as well as micronutrients, furthermore, it creates suitable environment for the activity of soil microorganisms (Fageria 2012).

Micronutrients are nutrients required by plants in small quantities throughout their life to organize a range of physiological functions. Although these elements are used in very small amounts, they are important to plant development and profitable crop production as the macronutrients. The soil in semi-arid regions is characterized by poor structure, low organic carbon content, high $\mathrm{pH}$, low cation exchange capacity and salinity/alkalinity problems, and these conditions increase micronutrient deficiencies (Marschner \& Rengel 2012). Among the micronutrients iron and zinc are essential for plant growth and food production. Fe is involved in the production of chlorophyll, photosynthesis, mitochondrial respiration, hormone biosynthesis (ethylene, gibberellic acid and jasmonic acid) production (Marschner \& Rengel 2012). Besides, zinc is a necessary component of various enzyme systems for energy production, protein synthesis; it maintains the structural integrity of biomembranes and growth regulation (Alloway 2008; Marschner \& Rengel 2012).

In recent years, some researchers tried to examine the potential of nanotechnology to improve efficiency of micronutrients uptake that result in the development of efficient new nano fertiliser delivery systems for field application (Naderi \& Danesh-Shahraki 2013; Rameshaiah \& Jpallavi 2015). Nano-formulated fertilisers can release nutrients more slowly in cooperation with other fertilisers which may lead to improvement of nutrient use efficiency. The application of zinc nano fertiliser on pearl millet improved some properties such as shoot length, root length, chlorophyll content, total soluble leaf proteins and plant dry biomass. The grain yield at crop maturity was improved by $37.7 \%$ due to application of zinc nano-fertiliser in pearl millet (Tarafdar et al.
2014). Faizan et al. (2017) concluded that presence of nano $\mathrm{Zn}$ enhanced the antioxidant systems and improved photosynthetic efficiency in tomato. The best fertiliser treatment for obtaining high seed yield was identified in sulfur plus nano zinc on chickpea (Sabaghnia \& Janmohammadi 2017). In Brassica napus (Zakerin et al. 2014) showed that, the maximum grain yield and oil yield were obtained from nano $\mathrm{Zn}+\mathrm{Fe}$ foliar application on barley.

The present research aims to investigate alternative source of chemical fertilisers using application of manure, and combination of manure fertiliser with foliar application of nano-iron and zinc on morphological, yield, chemical compositions represented in Methyl-thiobutyl-isothiocyanate (molecular weight: 161.3, $\mathrm{C}_{6} \mathrm{H}_{11} \mathrm{~N} \mathrm{~S}_{2}$ ) as a main component of essential oil and has been used in variety of medical (particularly breast and testis cancer), industry and cosmetic fields, beside fixed oil constitutes from seed yield of rocket plants.

\section{MATERIAL AND METHODS}

Present investigation was done at Kafr Tuhurmis, El-Giza Governorate, with the latitude of 30.021074 and the longitude is 31.173145 . Category with the Gps of $30^{\circ} 1^{\prime} 15.8664 " \mathrm{~N}$ and $31^{\circ} 10^{\prime} 23.3220^{\prime \prime} \mathrm{E}$. Elevation is a 24 meters height, Egypt. For four continues repeated seasons during 2015 and 2016, every two cuts represented as one season. Mechanical and chemical analyses of soil were performed at Soil \& Water and Environment Research Institute, Agriculture Research Center (A.R.C) according to Richards (1954) and Jackson (1973) shown in Table1.

\section{Plant material, transplant and harvest dates}

Seeds of (Eruca sativa Mill.) were obtained from experimental farm of Faculty of Pharmacy, Cairo University, and planted in an open area with a distance of $40 \mathrm{~cm}$ between rows, and $30 \mathrm{~cm}$ spacing between plants in plots with $3 \times 5 \mathrm{~m}^{2}$. The seeds were planted on February $5^{\text {th }}$ and the first cut was taken on March $14^{\text {th }}$, while the second cut was taken on April $15^{\text {th }} 2015$, both two cuts considered as the first season. The seeds were planted again on February $5^{\text {th }}$, the first cut was taken on March $15^{\text {th }}$, whereas the second one was taken on April $16^{\text {th }} 2016$; both two cuts considered as the second season. 
T a b 1 e 1

Some physical and chemical characteristics of clay soil used for growing Eruca sativa plant

\begin{tabular}{|l|c|}
\hline Parameter & Value \\
\hline Physical characteristics & Clay \\
\hline Texture & 40.50 \\
Clay [\%] & 35.10 \\
Silt [\%] & 21.00 \\
Fine sand [\%] & 3.40 \\
Coarse sand [\%] & 7.88 \\
$\mathrm{pH}$ & 1.63 \\
$\mathrm{EC}$ [dS/m] & 1.70 \\
Organic matter [\%] & \\
\hline $\mathrm{Chemical} \mathrm{characteristics}^{2}$ & \\
\hline Soluble cations [meq/l] & 7.22 \\
\hline $\mathrm{Ca}^{++}$ & 2.98 \\
$\mathrm{Mg}^{++}$ & 0.33 \\
$\mathrm{~K}^{+}$ & 6.22 \\
$\mathrm{Na}^{+}$ & \\
\hline Soluble anions [meq/l] & 3.50 \\
\hline $\mathrm{Cl}^{-}$ & 2.45 \\
$\mathrm{SO}_{4}^{-}$ & 30.10 \\
Available N [ppm] $_{\text {Available P [ppm] }}$ & 22.50 \\
\hline
\end{tabular}

\section{Land Preparation}

Before planting, the soil was first mechanically ploughed and planked twice till the soil surface has been settled, then plots established.

$$
\mathrm{T} \text { a }
$$

Some chemical analysis of used chicken manure used

\begin{tabular}{|l|r|}
\hline \multicolumn{2}{|c|}{ Parameter } \\
\hline \multicolumn{2}{|c|}{ Total macronutrients [\%] } \\
\hline $\mathrm{N}$ & 2.60 \\
$\mathrm{P}$ & 0.70 \\
$\mathrm{~K}$ & 1.15 \\
\hline \multicolumn{2}{|c|}{ Total micronutrients [ppm] } \\
\hline $\mathrm{Fe}$ & 26.5 \\
$\mathrm{Zn}$ & 34.3 \\
$\mathrm{Mn}$ & 16.0 \\
$\mathrm{Cu}$ & 28.5 \\
$\mathrm{pH}$ & 7.60 \\
$\mathrm{C} / \mathrm{N}$ ratio & 19.7 \\
Organic matter [\%] & 62.4 \\
\hline
\end{tabular}

\section{Chemical fertilisers added}

Chemical fertilisers as recommended dose according to Ministry of Agriculture and Land Reclamation were added at the rate of $50 \mathrm{~kg} / \mathrm{fed}$. (fadden equal $\left.4,200 \mathrm{~m}^{2}\right)$ of calcium superphosphate $(15.5 \%)$ after 10 days from planting, while $50 \mathrm{~kg} / \mathrm{fed}$. ammonium sulphate $(20.5 \%)$ and $20 \mathrm{~kg} / \mathrm{fed}$. of potassium sulphate $(40 \%)$ were added after every cut.

\section{Chicken manure added}

As Ministry of Agriculture and Land Reclamation recommended 5 tons/fed. chicken manure was added to the soil one week before plating.

\section{Nano Fe and Zn preparation and addition}

Nano iron was prepared with little modify from magnetite $\left(\mathrm{Fe}_{3} \mathrm{O}_{4}\right)$ of $\mathrm{Fe}^{3+}$ and $\mathrm{Fe}^{2+}$ at a molar ratio of $3: 2$ by reduction-precipitation in aqueous ammonia $(0.3 \mathrm{~mol} / \mathrm{L})$ and coated tetramethyl ammonium hydroxide under vigorous stirring for $2 \mathrm{~h}$ using magnetic stirring, precipitate was then separated by magnetic filtration using a permanent magnet, and washed with distilled water until a neutral $\mathrm{pH}$ was obtained according to Qu et al. (1999). While nano zinc was prepared from aqueous solution of zinc sulfate and sodium hydroxide solution was added slowly in a molar ratio of 1:2 under vigorous stirring for $8 \mathrm{~h}$. The precipitate obtained was filtered and washed thoroughly with ionized water. The precipitate was dried in an oven at $100^{\circ} \mathrm{C}$, then expose to 15 psi of pressure for 6 hours (Daneshvar et al. 2007).

TEM (transmission electronic microscope) Figure 1 ( $a \& b$ ) was done in TEM lab (FA-CURP) Faculty of Agriculture Cairo University Research Park to determine the nano size.

Both Fe and Zn nano particles at concentrations 20 and 40 ppm were applied to Eruca sativa plants as foliar at 10, 17 and 24 days after planting in both seasons.

\section{Treatments}

- NPK fertilisers (recommended doses) as control,

- Chicken Manure,

- Nano Fe and Zn,

- Nano Fe and $\mathrm{Zn}+$ chicken manure.

Data recorded

A. Plant growth parameters upon cuts

- Plant height [cm], 


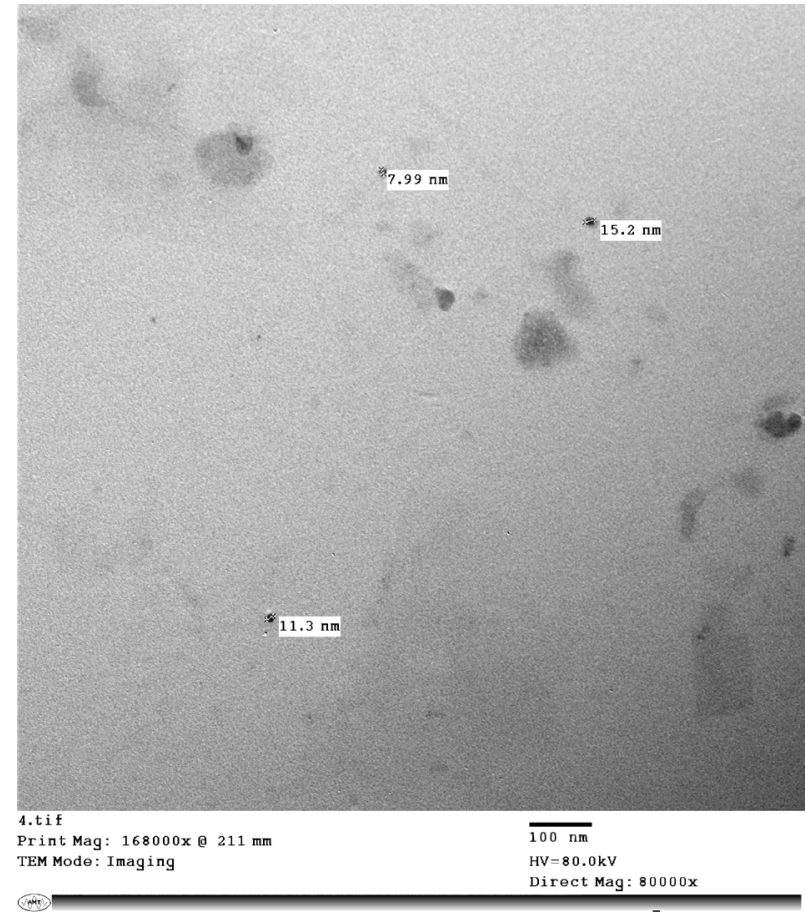

(a)

Figure 1. Zinc nano particles (a) - Iron nano particles (b)

- Leaf area $\left[\mathrm{m}^{2}\right]$,

- Plant fresh weight [g],

- Plant dry weight [g],

- Yield fresh weight [t/fadden],

- Seed yield [kg].

Ash percentage was determined quantitatively by grinding $2 \mathrm{~g}$ of leaves sample and combusting the material in a muffle furnace at $550^{\circ} \mathrm{C}$ to constant weight. The total ash content was calculated using the following formula:

$$
\%=\frac{\mathrm{A} \times 100}{\mathrm{~B}}
$$

where: A - weight of the ash in gram, B - weight of the anhydrous raw material in gram.

Moisture content was determined according to Tsand \& Frutani (1989).

\section{B. Chemical analysis}

The total nitrogen content of the dried leaves was determined by using the modified- micro-Kjeldahel

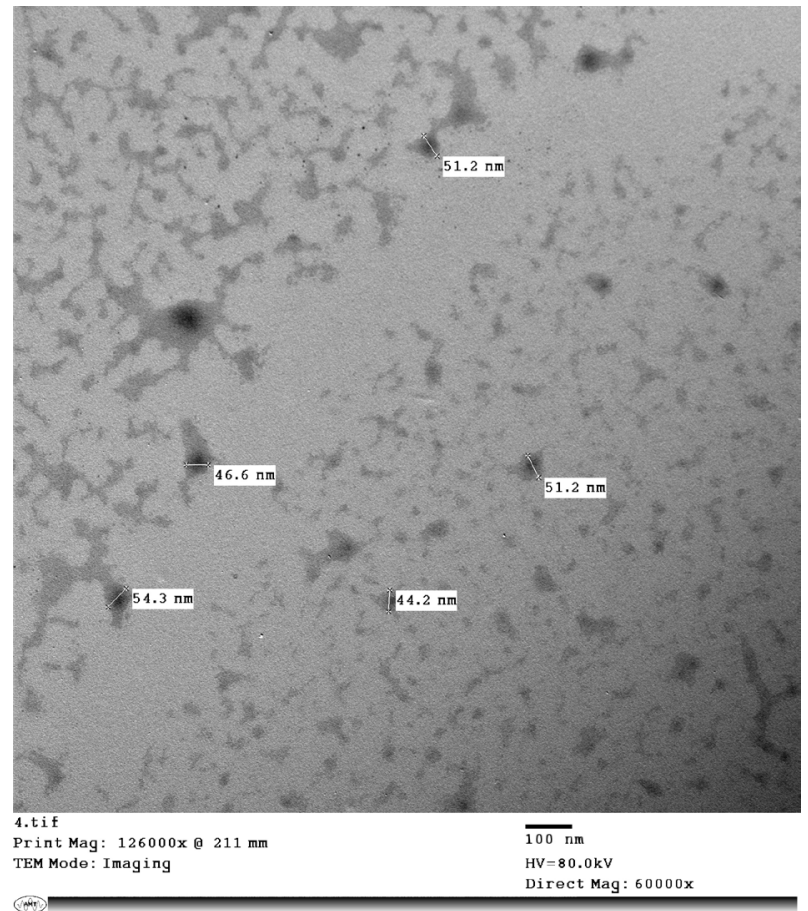

(b)

method as described by Helrich (1990). The nitrogen percentage was multiplied by 6.25 to estimate the crude protein percentages in leaves.

Phosphorus in leaves was determined calorimetrically by using the chloro-stannous molybdophosphoric blue color method in sulphuric acid according to Jackson (1973).

Potassium concentrations in leaves were determined by using the flame photometer apparatus (CORNING M 410, Germany).

Concentration of $\mathrm{Ca}, \mathrm{Mg}, \mathrm{Fe}, \mathrm{Mn}, \mathrm{Cu}, \mathrm{Ni}, \mathrm{Pb}$ and Zn were determined using Atomic Absorption Spectrophotometer with air-acetylene fuel (Pye Unicam, model SP-1900, US).

Plant pigments - total chlorophylls and carotenoids content were measured by spectrophotometer and calculated according to the equation described by Moran (1982).

Total carbohydrates in plant leaves were determined by phosphor molybdic acid method according to Helrich (1990).

Total phenolic contents of the extracts were determined spectrophotometrically according to the Folin-Ciocalteu colorimetric method (Singleton \& Rossi 1965). 
Vitamin - $C$ content as ascorbic acid [mg] was estimated in leaves fresh weight according to Helrich (1990) method using 2,6-dichloro phenolindophenol.

The sugars were separated on a chromatographic column filled with cation exchange resin (sulfonated polystyrene-divinylbenzene copolymer in the form of $\mathrm{Ca}^{2+}$ ). The mobile phase consisted of an aqueous solution of calcium disodium ethylene diamine tetraacetate. The eluted constituents were detected by a refractometric detector and determined by the external standard method.

Total flavonoids were determined using the method of Meda et al. (2005).

Tannin contents were determined using Folin-Ciocalteu reagent method as described by Chahardehi et al. (2009)

Endogenous phytohormones - the analysis was performed according to Fales and Jaouni (1973) for the determination of indole-acetic acid (IAA) and abscisic acid (ABA). The quantification of the endogenous phytohormones was carried out with Ati-Unicumgas-liquid chromatography, 610 Series, equipped with flame ionization detector according to the method described by Vogel (1975).

Net photosynthesis, stomatal conductance and water use efficiency

Measurements of net photosynthesis on an area basis $\left[\mu \mathrm{mol} \mathrm{CO} \mathrm{CO}_{2} / \mathrm{s}\right]$, leaf stomatal conductance [mol $\left.\mathrm{H}_{2} \mathrm{O} \mathrm{m} / \mathrm{s}\right]$, and water use efficiency of five different leaves per treatment was monitored using a LICOR 6400 (Lincoln, Nebraska, USA) infrared gas analyzer (IRGA). Light intensity (Photosynthetically active radiation, PAR) within the sampling chamber was set at $1,500 \mu \mathrm{mol} \mathrm{m} / \mathrm{s}$, using a Li-6400-02B LED light source (LI-COR). The $\mathrm{CO}_{2}$ flow into the chamber was maintained at a concentration of $400 \mu \mathrm{mol} / \mathrm{mol}$ using an LI-6400-01 $\mathrm{CO}_{2}$ mixer (LI-COR).

\section{Essential oil in leaves}

The leaves from E. sativa were hydro-distilled for 3 hours with a Likens-Nickerson-type apparatus, using diethyl ether to get yellowish oil yield.

\section{Gas chromatography}

GC-MS was carried out with a Hewlett-Packard with a flame ionization detector (FID) on a capillary column (TC-WAX FFS fused silica $60 \mathrm{~m} \times 0.25 \mathrm{~mm}$ i.d). The column temperature was programmed from $60^{\circ} \mathrm{C}$ to $240^{\circ} \mathrm{C}$ at a rate of $3^{\circ} \mathrm{C} / \mathrm{min}$ and held at $240^{\circ} \mathrm{C}$. The injector and detector temperatures were $250^{\circ} \mathrm{C}$ and $280^{\circ} \mathrm{C}$, respectively.

\section{Fixed oil content [\% of the seeds]}

Fixed oil was extracted from seeds by using a Soxhlet apparatus. The oil percentage was determined according to the methylation (change fixed oil into fatty acid) and GLC analysis was also recorded by GC according to Kinsella et al. (1977).

\section{GLC of fatty acid methyl esters}

Separation of fatty acid methyl esters was carried out using capillary column, which contained 15\% diethyl glycol succinate (DEGS). The injector port and flame ionization detector were set at $240^{\circ} \mathrm{C}$. The flow rate of carrier gas, nitrogen, was $10 \mathrm{ml} / \mathrm{min}$. The gas chromatograph (Perkin-Elemar model 8310) had a temperature program from 100 to $190^{\circ} \mathrm{C}$ with interment rate of $7^{\circ} \mathrm{C} /$ minute. The initial and final time were identified according to their retention time compared to those of authentic samples.

\section{Statistical analysis}

The experimental design was randomized complete blocks design with ten replicates. The data were analysed using ANOVA at 5\% significance level, the difference between treatments, then analysed using DMRT (Duncan Multiple Range Test) at level 5\% (Duncan 1955).

\section{RESULTS AND DISCUSSION}

\section{Growth parameters and yield}

Data related to growth parameters of the rocket plants using different types of fertilisers presented in Table 3 showed that, nano $\mathrm{Fe}$ and $\mathrm{Zn}$ combined with manure treatments had significantly stimulated growth characteristics with the highest values compared to all other treatments. The integrative nano $\mathrm{Fe}+\mathrm{Zn}+$ manure application significantly increased plant height, leaf area, plant fresh and dry weight, moisture and ash percentage over either control (recommended dose of NPK fertilisers) or other treatments, and consequently the yield of rocket plants during both seasons. 
According to Table 3, it is clear that mixed nano $\mathrm{Fe}$ and $\mathrm{Zn}$ with manure would not only result in high production of both fresh weight and seed yield but also improved the other desirable agronomic traits for market processes (plant height, leaf area, fresh weight and moisture). Moreover, the combination treatment significantly exceeded the growth parameter, and consequently the seed yield of rocket plants. This integrative addition exceeded seed yield by 26.6 and $14 \%$ as compared to NPK fertiliser in both seasons, respectively.

Results of the current study show that vegetative growth parameters were considerably improved by both manure and nano-micronutrient fertilisers. The association of manure and nano $\mathrm{Fe}+\mathrm{Zn}$ fertilisers may complement the lack of some nutrients of manure fertiliser. Organic manures applied in integration with the inorganic fertilisers gave higher yield than sole chemical fertilizers (Badawi et al. 2005; Sarwar et al. 2008). The beneficial effects of these treatments on rocket plant are due to nutrients availability to be absorbed by plant roots and improvement of soil's physical, chemical and biological properties as evident by higher water retention, decreased soil $\mathrm{pH}$, and increased soil organic.

The findings of present research are consistent with those of El-Ghamry et al. (2009) who found that, farmyard manure plays an important role in supplying some essential plant nutrients. Bala et al. (2014) reported that the beneficial role of nano-fertilisers on growth of chickpea had significant effects compared to control without nano-fertilisers. Furthermore, Amirnia et al. (2014) have emphasized the positive effects of some micronutrient and macronutrients nano-fertilisers (iron, phosphorus and potassium) on saffron (Crocus sativus L.) production. Liu et al. (2006) reported that, nano-particles application was safe for wheat production and has some economic benefits and has also shown that nanoparticles get into plant cells through either sto-

$\mathrm{T}$ a b 1 e 3

Effect of NPK, manure and nano Fe and $\mathrm{Zn}$ on growth characters of rocket plants during two seasons

\begin{tabular}{|c|c|c|c|c|c|c|c|c|}
\hline \multirow{2}{*}{ Treatment } & \multicolumn{2}{|c|}{ Plant height $[\mathrm{cm}]$} & \multicolumn{2}{|c|}{ Leaf area $\left[\mathrm{cm}^{2}\right]$} & \multicolumn{2}{|c|}{ Fresh weight /plant $[\mathrm{g}]$} & \multicolumn{2}{|c|}{ Dry weight $[\mathrm{g} /$ plant $]$} \\
\hline & F1 & F2 & F1 & F2 & F1 & $\mathrm{F} 2$ & F1 & F2 \\
\hline NPK & $24.3^{\mathrm{a}}$ & $22.5^{\mathrm{b}}$ & $67.16^{\mathrm{b}}$ & $69.43^{b}$ & $30.79^{b}$ & $32.85^{\mathrm{b}}$ & $7.32^{\mathrm{b}}$ & $8.41^{\mathrm{b}}$ \\
\hline Manure & $21.1^{\mathrm{b}}$ & $23.1^{\mathrm{b}}$ & $66.85^{\mathrm{b}}$ & $70.20^{\mathrm{b}}$ & $31.58^{\mathrm{b}}$ & $33.62^{\mathrm{b}}$ & $8.61^{\mathrm{b}}$ & $8.55^{\mathrm{b}}$ \\
\hline Nano $\mathrm{Fe}+\mathrm{Zn}$ & $20.7^{\mathrm{b}}$ & $22.2^{\mathrm{b}}$ & $68.02^{\mathrm{b}}$ & $70.13^{b}$ & $32.45^{\mathrm{b}}$ & $33.92^{\mathrm{b}}$ & $7.12^{\mathrm{b}}$ & $8.68^{b}$ \\
\hline $\begin{array}{l}\text { Nano } \mathrm{Fe}+\mathrm{Zn}+ \\
\text { manure }\end{array}$ & $25.3^{\mathrm{a}}$ & $30.3^{\mathrm{a}}$ & $71.11^{\mathrm{a}}$ & $75.42^{\mathrm{a}}$ & $40.35^{\mathrm{a}}$ & $43.77^{\mathrm{a}}$ & $10.36^{\mathrm{a}}$ & $12.36^{\mathrm{a}}$ \\
\hline \multirow[t]{2}{*}{ Treatment } & \multicolumn{2}{|c|}{$\begin{array}{c}\text { Moisture } \\
{[\% \text { dry matter }]}\end{array}$} & \multicolumn{2}{|c|}{$\begin{array}{c}\text { Ash } \\
{[\% \text { dry matter }]}\end{array}$} & \multicolumn{2}{|c|}{$\begin{array}{l}\text { Yield F. W. } \\
\text { [t/fed.] }\end{array}$} & \multicolumn{2}{|c|}{$\begin{array}{c}\text { Seed yield } \\
{[\mathrm{kg} / \mathrm{fed} .]}\end{array}$} \\
\hline & F1 & F2 & F1 & F2 & F1 & F2 & F1 & F2 \\
\hline NPK & $6.14^{\mathrm{b}}$ & $7.12^{\mathrm{b}}$ & $16.22^{\mathrm{b}}$ & $17.31^{\mathrm{b}}$ & $11.12^{\mathrm{b}}$ & $12.14^{\mathrm{b}}$ & $310.2^{\mathrm{c}}$ & $364.5^{\mathrm{c}}$ \\
\hline Manure & $7.24^{\mathrm{b}}$ & $7.15^{\mathrm{b}}$ & $17.25^{\mathrm{b}}$ & $18.28^{\mathrm{b}}$ & $11.51^{\mathrm{b}}$ & $12.73^{\mathrm{b}}$ & $340.2^{\mathrm{b}}$ & $369.7^{\mathrm{b}}$ \\
\hline Nano $\mathrm{Fe}+\mathrm{Zn}$ & $6.18^{\mathrm{b}}$ & $7.14^{\mathrm{b}}$ & $16.19^{\mathrm{b}}$ & $17.44^{\mathrm{b}}$ & $11.14^{\mathrm{b}}$ & $12.79^{b}$ & $308.5^{\mathrm{c}}$ & $365.2^{\mathrm{c}}$ \\
\hline $\begin{array}{l}\text { Nano } \mathrm{Fe}+\mathrm{Zn}+ \\
\text { manure }\end{array}$ & $8.15^{\mathrm{a}}$ & $9.23^{\mathrm{a}}$ & $21.15^{\mathrm{a}}$ & $23.45^{\mathrm{a}}$ & $14.29^{\mathrm{a}}$ & $15.30^{\mathrm{a}}$ & $392.8^{\mathrm{a}}$ & $416.5^{\mathrm{a}}$ \\
\hline
\end{tabular}

Means with the same letter in a column are not significantly different by DMRT at level 5\%

F1 - first season; F2 - second season 
matal or vascular system. Our results also showed that the highest seed yield was related to nano $\mathrm{Zn}+$ Fe manure as compared to manure fertiliser alone. Nanoparticles with small size and large surface area are expected to be the ideal material for use as a fertiliser in plants. When materials are transformed to a nano-scale, their physical, chemical and biological characteristics as well as catalytic properties even more increased (Mazaherinia et al. 2010). In this subject Eichert et al. (2008) suggested that, stomatal pathway is highly capacitive because of its large size exclusion limit and its high transport velocity. These scientific reports support the present hypothesis of nanoparticle penetration plant cell through stomatal opening and natural nano-pore which may enhance plant cell metabolic activities hence, lead to higher plant production (Mosanna \& Behrozyar 2015).

Plant pigments, carbohydrates, phenols, alkaloids, tannins and flavonoids concentrations

It is evident from Table 4, that manure fertiliser combined with nano $\mathrm{Fe}+\mathrm{Zn}$, lead to significant increases in the mean values of chlorophyll, carotenoids, carbohydrates, phenols, alkaloids, tannins and flavonoids concentrations compared with the NPK treatment (control). Total chlorophyll statistically increased by (29.5 and $25.4 \%$ ) over control during both seasons, respectively, while the increase was bigger than double in concentration of carotenoids. It reached (128 and 120\%) during both seasons compared with control. For the carbohydrates and phenols percentage, the presented data revealed that the combined treatment of nano $\mathrm{Fe}+\mathrm{Zn}+$ manure enhanced the accumulation by (30.3-27.8\%) and (31.9-30.4\%), respectively as compared to control plants during the two seasons. The same trend was found for alkaloids, tannins and flavonoids percentage.

Previous researches indicated that, fertilisation type had an influence on the phyto-nutritional quality of crops. Chemical fertilisers are believed to reduce the antioxidant levels while organic fertilisers were proven to enhance the antioxidant content in plants (Dumas et al. 2003). In tomato, the presence of zinc oxide nano-particles improved the antioxidant systems and photosynthetic efficiency as well (Faizan et al. 2017). The increase in total carbohydrates may be due to the increase of photosynthesis (Figure 2) as a result of increase in photosynthetic pigments content in leaves (Table 4). Manure appears to be a source of a number of essential elements that may play an important role in plant metabolism, notably the most significant function would appear to involve carbohydrate metabolism and photosynthesis (Tisdale \& Nelson 1975). These results are in agreement with those obtained from Leclerc et al.

$\mathrm{T}$ a $\mathrm{b} 1$ e 4

Effect of NPK, manure and nano Fe and Zn on chemical characters of rocket plants during two seasons

\begin{tabular}{|c|c|c|c|c|c|c|c|c|c|c|c|c|c|c|}
\hline \multirow[t]{2}{*}{ Treatment } & \multicolumn{2}{|c|}{$\begin{array}{c}\text { Total } \\
\text { chlorophyll } \\
\text { F.W. [mg/g] }\end{array}$} & \multicolumn{2}{|c|}{$\begin{array}{c}\text { Total } \\
\text { carotenoids } \\
\text { F.W. }[\mathrm{mg} / \mathrm{g}]\end{array}$} & \multicolumn{2}{|c|}{$\begin{array}{c}\text { Total } \\
\text { carbohydrates } \\
{[\%]}\end{array}$} & \multicolumn{2}{|c|}{$\begin{array}{c}\text { Total phenols } \\
{[\%]}\end{array}$} & \multicolumn{2}{|c|}{$\begin{array}{c}\text { Total alkaloids } \\
{[\%]}\end{array}$} & \multicolumn{2}{|c|}{$\begin{array}{c}\text { Tannins } \\
{[\%]}\end{array}$} & \multicolumn{2}{|c|}{$\begin{array}{c}\text { Total } \\
\text { flavonoids } \\
{[\%]}\end{array}$} \\
\hline & F1 & $\mathrm{F} 2$ & F1 & $\mathrm{F} 2$ & F1 & $\mathrm{F} 2$ & F1 & $\mathrm{F} 2$ & F1 & $\mathrm{F} 2$ & F1 & $\mathrm{F} 2$ & F1 & $\mathrm{F} 2$ \\
\hline NPK & $28.42^{\mathrm{c}}$ & $30.51^{\mathrm{c}}$ & $3.03^{\mathrm{c}}$ & $3.58^{\mathrm{c}}$ & $17.43^{b}$ & $19.42^{c}$ & $58.29^{c}$ & $61.58^{c}$ & $10.43^{c}$ & $12.46^{c}$ & $51.42^{b}$ & $48.11^{\mathrm{c}}$ & $20.52^{b}$ & $18.41^{\mathrm{c}}$ \\
\hline Manure & $30.58^{\mathrm{b}}$ & $32.71 b$ & $4.88 \mathrm{~b}$ & $5.61^{\mathrm{b}}$ & $18.39^{b}$ & $21.52^{b}$ & $63.29^{b}$ & $66.41^{\mathrm{b}}$ & $12.82^{b}$ & $13.71^{b}$ & $47.33^{c}$ & $50.30^{\mathrm{b}}$ & $20.39^{b}$ & $22.58^{b}$ \\
\hline Nano $\mathrm{Fe}+\mathrm{Zn}$ & $34.21^{\mathrm{b}}$ & $37.08^{\mathrm{a}}$ & $4.57^{\mathrm{b}}$ & $5.49^{b}$ & $17.58^{b}$ & $21.17^{\mathrm{b}}$ & $60.72^{c}$ & $62.35^{\mathrm{c}}$ & $12.24^{\mathrm{b}}$ & $12.44^{\mathrm{c}}$ & $45.97^{\mathrm{c}}$ & $51.21^{\mathrm{b}}$ & $22.68^{\mathrm{a}}$ & $22.79^{b}$ \\
\hline $\begin{array}{l}\text { Nano } \mathrm{Fe}+\mathrm{Zn} \\
+ \text { manure }\end{array}$ & $36.79^{a}$ & $38.26^{\mathrm{a}}$ & $6.92^{\mathrm{a}}$ & $7.89^{\mathrm{a}}$ & $22.75^{\mathrm{a}}$ & $24.83^{\mathrm{a}}$ & $76.91^{\mathrm{a}}$ & $80.31^{a}$ & $14.09^{\mathrm{a}}$ & $14.85^{\mathrm{a}}$ & $52.67^{\mathrm{a}}$ & $53.27^{\mathrm{a}}$ & $23.95^{\mathrm{a}}$ & $25.78^{\mathrm{a}}$ \\
\hline
\end{tabular}

Means with the same letter in a column are not significantly different by DMRT at level 5\%

F1 - first season; F2 - second season 
(1991) on carrot and Soliman \& Mahmoud (2013) on Adansonia digitata L. Zn application in wheat could alleviate the oxidative stress of wheat through transcriptional regulation of multiple defense pathways, such as antioxidant enzymes and flavonoid secondary metabolism (Ma et al. 2017). Organic fertilisation has a stimulatory effect on accumulation of phenolics in fennel; it is well known that, the higher concentrations of phenolics can be explained by the role of organic fertilisers inducing the acetate shikimate pathway, resulting in higher production of flavonoids and phenolics (Sousa et al. 2008). Furthermore, the chlorophyll concentration noticeably responded to nutrients management and the highest value was obtained by combined application of manure and nano Fe plus $\mathrm{Zn}$. There is a close relationship between the capacity of photosynthetic carbon dioxide fixation and the chlorophyll concentration. Therefore, the increase in the chlorophyll concen-
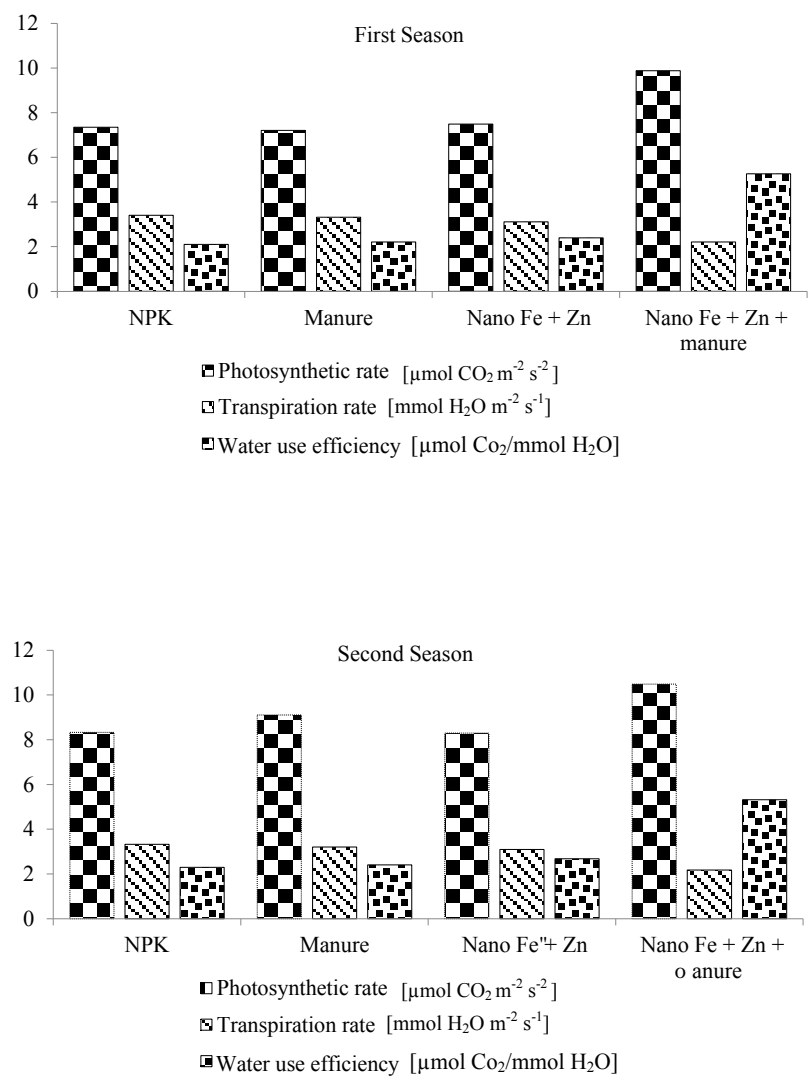

Figure 2. Effect of NPK, manure and nano Fe, nano Zn treatments on photosynthetic rate, transpiration rate and water use efficiency of Eruca sativa plant during two seasons tration can be considered equivalent to the increased source strength represented in the export rate of a photo-assimilates from the source tissue (White et al. 2016).

Photosynthetic rate, transpiration rate and water use efficiency

Data of photosynthetic rate, transpiration rate and water use efficiency of the rocket plants fertilised with NPK, manure fertiliser or nano $\mathrm{Fe}+\mathrm{Zn}$ individually and in combination with manure are presented in Figure 2. It was cleared that application of nano $\mathrm{Fe}+$ nano $\mathrm{Zn}$ fertilisers mixed with manure fertiliser significantly increased photosynthetic rate and water use efficiency (WUE) as compared to control in both seasons. Although, the application of NPK or manure treatments or nano Fe plus nano Zn individually were observed to show in significant differences for photosynthetic rate and water use efficiency. Application of nano $\mathrm{Fe}+$ nano $\mathrm{Zn}$ mixed with manure fertiliser significantly increased WUE which reached 5.26 and $5.32 \mu \mathrm{mol} \mathrm{CO}_{2} / \mathrm{mmol} \mathrm{H}_{2} \mathrm{O}$ as compared with control $(2.10$ and $2.3 \mu \mathrm{mol} \mathrm{CO} /$ mmol $\mathrm{H}_{2} \mathrm{O}$ ) in both seasons, respectively.

This might be due to the greater yield obtained where the capacity of the plant to store the moisture would also increase its water use and converting into the yield per unit of water applied (Beheshti \& Fard 2010). The inorganic amendments were also found to have greater WUE over the control. Karasahin (2015) reported that, greater water use efficiency by the use of inorganic fertilisers than the organic manures. Nitrogen fertiliser increases the efficiency of water use by wheat (Deng et al. 2004). Positive effect on WUE was reported with Subhan et al. (2017) who found that, the inorganic fertilisers gave significant higher total dry matter, grain and straw yield and also due to the greater grain yield. The calculated WUE was greater in the NPK treatment as compared with organic manure; it's worth mentioning that, WUE is important parameters in the water scarce areas.

Enhancement values in photosynthetic rate 34.3 and $25.8 \%$ (Figure 2) with same previous mixed application may be due to increasing of leaf area (5.9 and 8.6\%) (Table 3) and chlorophyll content (29.5 and $25.4 \%$ ) over control (Table 4). Meanwhile, leaf numbers and leaf area are noticeably affected by 
both organic and inorganic fertilisers. The leaves are the most important photosynthetic organ and assimilate supplying source that play critical roles in light interception, evapotranspiration and significant response to fertilisers (Pandey \& Singh 2011). Increasing leaf area can directly affect the rate of photosynthetic (Evans \& Sadler 2007). The chlorophyll contents were enhanced by (20.71\%), and the net photosynthetic rate was promoted by $(31.87 \%)$ as compared with the control in spinach plants (Gao et al. 2006).

\section{Macro and micro nutrients concentrations}

When investigated Tables 5 and 6, we could found that a significant increase in $\mathrm{N}, \mathrm{P}$, and $\mathrm{K}$ concentrations were recorded as a result of nano $\mathrm{Fe}+$ nano $\mathrm{Zn}+$ manure application over control (NPK). In both seasons, combination treatment showed an increase in N (61 and 35\%), P (33 and 55\%), K (55 and $49 \%$ ), respectively compared to control treatments. Also the same treatment showed an increase concentrations of $\mathrm{N}$ (29.7 and 27.6\%), P (71 and $65.5 \%)$, and $\mathrm{K}$ (113.6 and $106.8 \%)$, respectively compared to manure treatment alone. In addition to these results, with combination treatment $\mathrm{Mg}$ content was increased by 25 and $20 \%$ as compared to NPK treatment. Generally, addition of nano Fe + nano $\mathrm{Zn}$ alone led to reduce the accumulation of all macro-elements in comparison with other treatments. The results of combined treatment application as well as individual treatment of manure or NPK were increased $\mathrm{Ca}$ content significantly than the results of addition of nano $\mathrm{Fe}+$ nano $\mathrm{Zn}$ alone.
Meanwhile, $\mathrm{Mn}, \mathrm{Fe}, \mathrm{Cu}, \mathrm{Zn}, \mathrm{Pb}$ and $\mathrm{Ni}$ exhibited an increasing trend in response to manure application (Table 6).

Several recent articles have articulated the benefits of nano-scale micronutrients to crop yield enhancement as well as the accumulation of nutrients. For example, Nasri et al. (2010) stated that, the use of iron and zinc nano-nutrients caused 12\% increment in amount of nitrogen in corn grain, indicating the role of these elements in increasing nitrogen percentage. Raliyaan \& Tarafdar (2013) and Raliya et al. (2016) reported that increases in plant growth, yield, and nutrient content upon treatment with nano ZnO. Similarly, Subbaiah et al. (2016) demonstrated that, nano $\mathrm{ZnO}$ increased growth, yield, and $\mathrm{Zn}$ content of maize. Still, the agronomic effectiveness of nano practical compared to non-nano forms of micronutrients has yet to be fully resolved (Mahmoud et al. 2017).

On the contrary, according to Trinchera et al. (2008) chemical fertilisation is able to supply greater amounts of nitrogen to plants in a brief period to improve better metabolism without needing for additional activity of enzymes, however, in case of plants receiving the organic fertilisers, may face a condition of slowly releasing the available nitrogen. This slow release of $\mathrm{N}$ may be considered as adverse environmental conditions due to nutrient deficiency.

Main sulphur content, glucose, fructose, ascorbic and crude protein contents

Going with main sulphur content represented in

$\mathrm{T}$ a $\mathrm{b} 1$ e 5

Effect of NPK, manure and nano $\mathrm{Fe}$ and $\mathrm{Zn}$ on macro-elements of rocket plants during two seasons

\begin{tabular}{|l|c|c|c|c|c|c|c|c|c|c|}
\hline \multirow{2}{*}{ Treatment } & \multicolumn{2}{|c|}{$\mathrm{N}[\%]$} & \multicolumn{2}{c|}{$\mathrm{P}[\%]$} & \multicolumn{2}{c|}{$\mathrm{K}[\%]$} & \multicolumn{2}{c|}{$\mathrm{Mg}[\%]$} & \multicolumn{2}{c|}{$\mathrm{Ca}[\%]$} \\
\cline { 2 - 10 } & $\mathrm{F} 1$ & $\mathrm{~F} 2$ & $\mathrm{~F} 1$ & $\mathrm{~F} 2$ & $\mathrm{~F} 1$ & $\mathrm{~F} 1$ & $\mathrm{~F} 2$ & $\mathrm{~F} 1$ & $\mathrm{~F} 2$ & $\mathrm{~F} 1$ \\
\hline NPK & $2.33^{\mathrm{b}}$ & $2.97^{\mathrm{c}}$ & $0.27^{\mathrm{b}}$ & $0.31^{\mathrm{b}}$ & $3.30^{\mathrm{b}}$ & $3.61^{\mathrm{b}}$ & $0.12^{\mathrm{b}}$ & $0.15^{\mathrm{b}}$ & $1.25^{\mathrm{a}}$ & $1.36^{\mathrm{a}}$ \\
Manure & $2.89^{\mathrm{b}}$ & $3.15^{\mathrm{b}}$ & $0.21^{\mathrm{c}}$ & $0.29^{\mathrm{b}}$ & $2.19^{\mathrm{c}}$ & $2.78^{\mathrm{c}}$ & $0.15 \mathrm{a}$ & $0.17 \mathrm{a}$ & $1.26 \mathrm{a}$ & $1.38 \mathrm{a}$ \\
Nano Fe $+\mathrm{Zn}$ & $1.94^{\mathrm{c}}$ & $2.85^{\mathrm{c}}$ & $0.19^{\mathrm{c}}$ & $0.25^{\mathrm{c}}$ & $2.17^{\mathrm{c}}$ & $2.58^{\mathrm{c}}$ & $0.10^{\mathrm{b}}$ & $0.13^{\mathrm{c}}$ & $1.24^{\mathrm{b}}$ & $1.35^{\mathrm{b}}$ \\
$\begin{array}{l}\text { Nano Fe }+\mathrm{Zn}+ \\
\text { manure }\end{array}$ & $3.75^{\mathrm{a}}$ & $4.02^{\mathrm{a}}$ & $0.36^{\mathrm{a}}$ & $0.48^{\mathrm{a}}$ & $4.68^{\mathrm{a}}$ & $5.75^{\mathrm{a}}$ & $0.15^{\mathrm{a}}$ & $0.18^{\mathrm{a}}$ & $1.34^{\mathrm{a}}$ & $1.49^{\mathrm{a}}$ \\
\hline
\end{tabular}

Means with the same letter in a column are not significantly different by DMRT at level 5\%

F1- first season; F2 - second season 


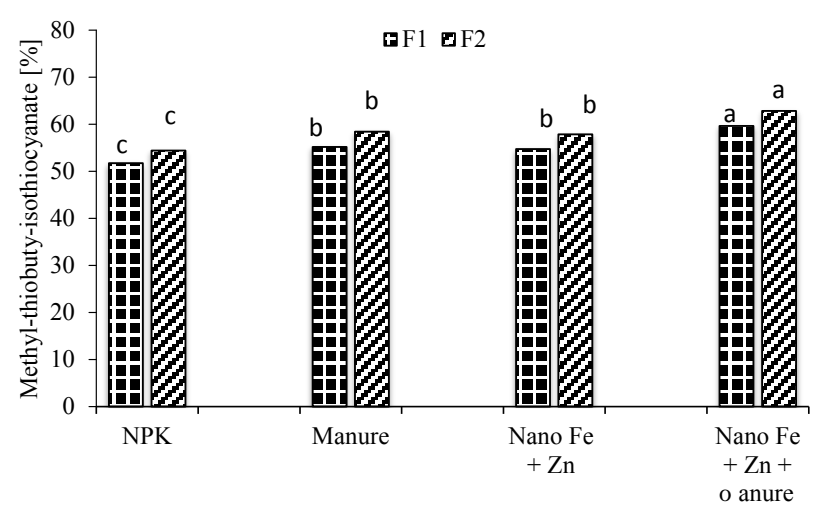

Figure 3. Effect of NPK, manure and nano $\mathrm{Fe}$ and $\mathrm{Zn}$ treatments on main sulphur content F1 - first season; F2 - second season methyl-thiobutyl-isothiocyanate (Figure 3), glucose and fructose contents (Table 7), significantly increased due to application of either manure fertiliser alone or nano $\mathrm{Fe}+\mathrm{Zn}$ or combination treatment over control. It was found that, combination treatment had a profound effect on methyl-thiobutyl-isothiocyanate (15.3 and $15.5 \%$ ) during both seasons, respectively in comparison to control plants. Also the maximum improvements in ascorbic and crude protein were observed due to manure fertiliser and combination treatment applied of manure and nano $\mathrm{Fe}+\mathrm{Zn}$ over both control and nano $\mathrm{Fe}+\mathrm{Zn}$ individually. The integrative treatment increased crude protein, glucose and fructose contents (61 and 36\%), (31 and 30\%), (90 and 98.5\%), respec-

T a b 1 e 6

Effect of NPK, manure and nano Fe and $\mathrm{Zn}$ on micro-elements of rocket plants during two seasons

\begin{tabular}{|l|c|c|c|c|c|c|c|c|c|c|c|c|}
\hline \multirow{2}{*}{ Treatment } & \multicolumn{2}{c|}{$\begin{array}{c}\mathrm{Mn} \\
{[\mathrm{ppm}]}\end{array}$} & \multicolumn{2}{c|}{$\begin{array}{c}\mathrm{Fe} \\
{[\mathrm{ppm}]}\end{array}$} & \multicolumn{2}{c|}{$\begin{array}{c}\mathrm{Cu} \\
{[\mathrm{ppm}]}\end{array}$} & \multicolumn{2}{c|}{$\begin{array}{c}\mathrm{Zn} \\
{[\mathrm{ppm}]}\end{array}$} & \multicolumn{2}{c|}{$\begin{array}{c}\mathrm{Pb} \\
{[\mathrm{ppm}]}\end{array}$} & $\begin{array}{c}\mathrm{Ni} \\
{[\mathrm{ppm}]}\end{array}$ \\
\cline { 2 - 12 } & $\mathrm{F} 1$ & $\mathrm{~F} 2$ & $\mathrm{~F} 1$ & $\mathrm{~F} 2$ & $\mathrm{~F} 1$ & $\mathrm{~F} 2$ & $\mathrm{~F} 1$ & $\mathrm{~F} 2$ & $\mathrm{~F} 1$ & $\mathrm{~F} 2$ & $\mathrm{~F} 1$ & $\mathrm{~F} 2$ \\
\hline NPK & $103.1^{\mathrm{c}}$ & $107.3^{\mathrm{c}}$ & $90.2^{\mathrm{c}}$ & $99.4^{\mathrm{c}}$ & $22.6^{\mathrm{a}}$ & $19.3^{\mathrm{a}}$ & $28.3^{\mathrm{c}}$ & $30.5^{\mathrm{c}}$ & $9.33^{\mathrm{b}}$ & $7.21^{\mathrm{b}}$ & $0.12^{\mathrm{b}}$ & $0.11^{\mathrm{b}}$ \\
Manure & $110.8^{\mathrm{b}}$ & $111.5^{\mathrm{b}}$ & $112.3^{\mathrm{b}}$ & $114.1^{\mathrm{b}}$ & $20.8^{\mathrm{b}}$ & $23.3^{\mathrm{a}}$ & $31.7^{\mathrm{b}}$ & $33.4^{\mathrm{b}}$ & $11.7^{\mathrm{a}}$ & $13.5^{\mathrm{a}}$ & $0.21 \mathrm{a}$ & $0.13 \mathrm{a}$ \\
$\begin{array}{l}\text { Nano Fe }+\mathrm{Zn} \\
\text { Nano Fe }+\mathrm{Zn}+ \\
\text { manure }\end{array}$ & $104.4^{\mathrm{c}}$ & $104.7^{\mathrm{d}}$ & $110.2^{\mathrm{b}}$ & $113.3^{\mathrm{b}}$ & $22.1^{\mathrm{a}}$ & $20.7^{\mathrm{a}}$ & $34.5^{\mathrm{a}}$ & $36.4^{\mathrm{a}}$ & $7.12^{\mathrm{c}}$ & $6.09^{\mathrm{b}}$ & $0.10^{\mathrm{c}}$ & $0.09^{\mathrm{c}}$ \\
& $112.4^{\mathrm{a}}$ & $118.7^{\mathrm{a}}$ & $114.8^{\mathrm{a}}$ & $117.9^{\mathrm{a}}$ & $24.9^{\mathrm{a}}$ & $24.8^{\mathrm{a}}$ & $35.4^{\mathrm{a}}$ & $38.7^{\mathrm{a}}$ & $12.5^{\mathrm{a}}$ & $13.2^{\mathrm{a}}$ & $0.19^{\mathrm{a}}$ & $0.14^{\mathrm{a}}$ \\
\hline
\end{tabular}

Means with the same letter in a column are not significantly different by DMRT at level 5\%

F1 - first season; F2 - second season

$\mathrm{T}$ a b 1 e 7

Effect of NPK, manure and nano $\mathrm{Fe}$ and $\mathrm{Zn}$ on chemical constituents of rocket plants during two seasons

\begin{tabular}{|l|c|c|c|c|c|c|c|c|}
\hline \multirow{2}{*}{ Treatment } & \multicolumn{2}{|c|}{$\begin{array}{c}\text { Ascorbic acid } \\
{[\mathrm{mg} / 100 \mathrm{~g}]}\end{array}$} & \multicolumn{2}{c|}{$\begin{array}{c}\text { Crude protein } \\
{[\%]}\end{array}$} & \multicolumn{2}{c|}{$\begin{array}{c}\text { Glucose [\%] } \\
\text { [g/100 g F.W. }\end{array}$} & \multicolumn{2}{c|}{$\begin{array}{c}\text { Fructose [\%] } \\
\text { [g/100 g F.W.] }\end{array}$} \\
\cline { 2 - 9 } & $\mathrm{F} 1$ & $\mathrm{~F} 2$ & $\mathrm{~F} 1$ & $\mathrm{~F} 2$ & $\mathrm{~F} 1$ & $\mathrm{~F} 2$ & $\mathrm{~F} 1$ & $\mathrm{~F} 2$ \\
\hline NPK & $48.55^{\mathrm{c}}$ & $51.82^{\mathrm{c}}$ & $14.56^{\mathrm{c}}$ & $18.50^{\mathrm{c}}$ & $1.16^{\mathrm{c}}$ & $1.24^{\mathrm{c}}$ & $1.26^{\mathrm{c}}$ & $1.4^{\mathrm{c}}$ \\
Manure & $50.11^{\mathrm{b}}$ & $53.71^{\mathrm{b}}$ & $18.06^{\mathrm{b}}$ & $20.1^{\mathrm{b}}$ & $2.2^{\mathrm{b}}$ & $2.46^{\mathrm{b}}$ & $1.96^{\mathrm{b}}$ & $2.24^{\mathrm{b}}$ \\
Nano Fe $+\mathrm{Zn}$ & $47.38^{\mathrm{c}}$ & $50.94^{\mathrm{c}}$ & $12.12^{\mathrm{d}}$ & $17.81^{\mathrm{c}}$ & $4.4^{\mathrm{a}}$ & $3.68^{\mathrm{b}}$ & $2.14^{\mathrm{a}}$ & $1.76^{\mathrm{c}}$ \\
$\begin{array}{l}\text { Nano Fe }+\mathrm{Zn}+ \\
\text { manure }\end{array}$ & $54.92^{\mathrm{a}}$ & $56.38^{\mathrm{a}}$ & $23.43^{\mathrm{a}}$ & $25.12^{\mathrm{a}}$ & $4.74^{\mathrm{a}}$ & $5.02^{\mathrm{a}}$ & $2.56^{\mathrm{a}}$ & $2.78^{\mathrm{a}}$ \\
\hline
\end{tabular}

Means with the same letter in a column are not significantly different by DMRT at level 5\%

F1- first season; F2 - second season 
tively compared with NPK for both seasons.

The increase in sulphur, ascorbic, crude protein, glucose and fructose contents may be due to advantageous effects of the manure and nano $\mathrm{Fe}+\mathrm{Zn}$ resulting in extra release of nutrients in an accessible form for plant uptake, which resulted in higher efficiency of the photosynthesis process, increasing synthesis of afore mentioned chemical constituents.

Results in Figure 4 revealed that, manure fertilisation had a great impact on formation of free fatty acids content, meanwhile application of either manure only or nano $\mathrm{Fe}+\mathrm{Zn}+$ manure resulted in a significant increase in free fatty acids content of rocket seed as compared to NPK treatment during the two seasons. The highest lauric, oleic and behenic acids contents were observed with both manure fertiliser alone and nano $\mathrm{Fe}+\mathrm{Zn}+$ manure in $1^{\text {st }}$ and $2^{\text {nd }}$ seasons as compared with NPK. While, the highest accumulation of palmitic, eicosenoic and erucic acids were obtained with combination
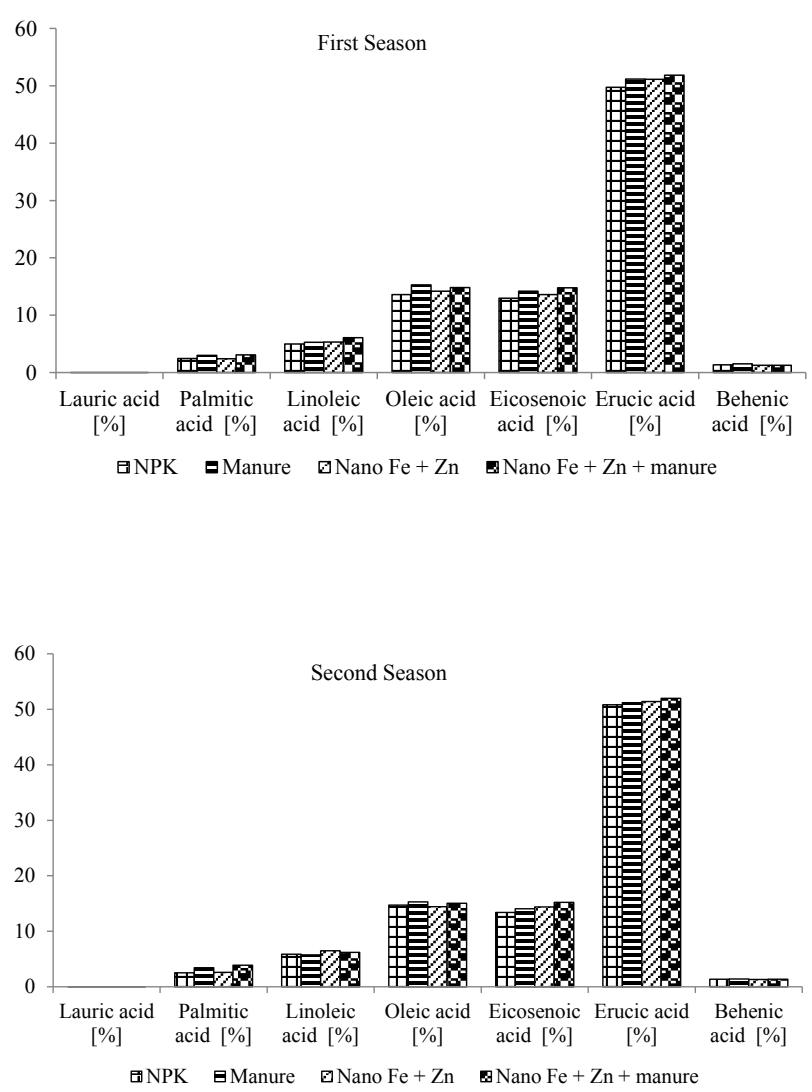

Figure 4. Effect of NPK, manure and treatments on percentage of some fatty acids content of seed oil of rocket plants during two seasons treatment compared with other treatments. As for the individual treatment of nano $\mathrm{Fe}+$ nano $\mathrm{Zn}$, produced the highest percentage of linoleic acid in the second season, whereas the combination treatment produced the best amount in the first season.

The increase in essential oil productivity with manure alone or combination treatment compared with control treatment could be explained on the basis of available elements, vitamins, hormone-like substances, amino acids and sugars, which have a significant effect on the physiological or biochemical processes within the plant and consequently boost essential oil yield. These results coincide with those obtained by Mahmoud (2012) on yarrow plant (Achillea millefolium) who stated that application of compost mixed with zeolite, humic acids and biofertilisers increased oil yield. In sunflowers under non-manure conditions, the application of the nanofertilisers could not affect the oil content, while the application of nano $\mathrm{Zn}$ and $\mathrm{Fe}$ under manure conditions significantly improved oil yield (Janmohammadi et al. 2016). Other researchers found that combination of the organic sources with inorganic nutrients gives higher oil content in rapeseed and Indian mustard (Tripathi et al. 2011). It has been revealed that nutrient management can affect the fatty acids biosynthesis pathway in oil crops and it seems that under nutritional imbalance a large proportion of photosynthates are diverted to protein formation. Deficiency of carbohydrates may stimulate the degradation fatty acids to acetyl co-enzyme $\mathrm{A}$ and it leads to decreased oil content (Marschner \& Rengel 2012). Also, Mahmoud et al. (2017) concluded that application of organic fertilisers, natural soil amendments and chemical fertilisers (nano form) produced higher growth characteristics, chemical composition and oil yield in comparison with results derived from chemical fertilisers NPK on caraway plant.

\section{Phytohormones concentrations}

The results of hormonal analysis represented in abscisic acid (ABA) and indole acetic acid (IAA) in rocket plant as affected by different treatments are displayed in Figures 5 and 6 . The increase of growth parameter was associated with high level of growth promoter (IAA) and low level of ABA. Hence it was found that nano $\mathrm{Fe}+$ nano $\mathrm{Zn}$ under manure fertiliser treatment gave significantly the highest content 
of IAA over all other treatments including control (NPK) in both season. The increases were mainly (52 and $92.7 \%$ ), respectively over control in the $1^{\text {st }}$ and $2^{\text {nd }}$ seasons.

It was established that, zinc was considered as an essential micronutrient for normal growth, development, and health of plants and human. Zinc enhances cation-exchange capacity of the roots, which in turn enhances absorption of essential nutrients, especially nitrogen which is responsible for higher protein content. Zinc plays a vital role in carbohydrate and proteins metabolism as well as it controls plant growth hormone IAA. $\mathrm{Zn}$ is also an essential component of dehydrogenase, proteinase, and peptides enzymes as well as promotes starch formation, seed maturation and production (Fageria et al. 2002). Besides, it controls the synthesis of indole acetic acid, a phytohormone which intensely regulates the plant growth, as well as necessary for chlorophyll synthe-

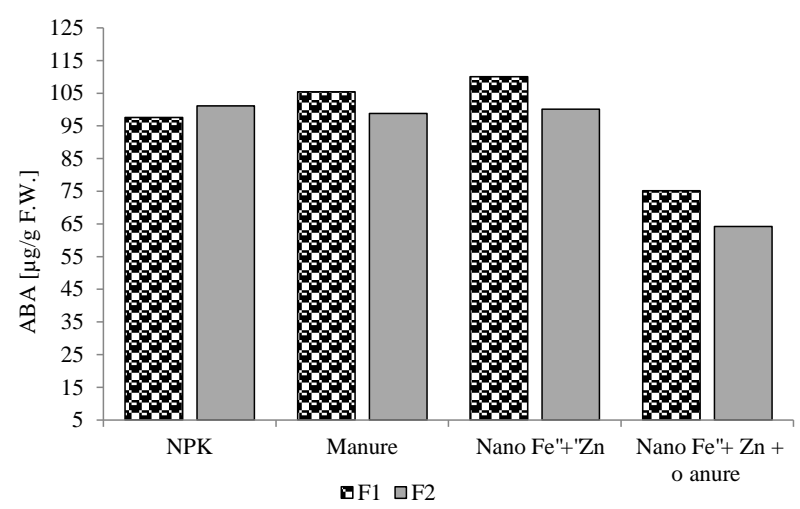

Figure 5. Effect of NPK, manure and nano Fe and $\mathrm{Zn}$ on ABA concentration of rocket plants during two seasons F1 - first season; F2 - second season

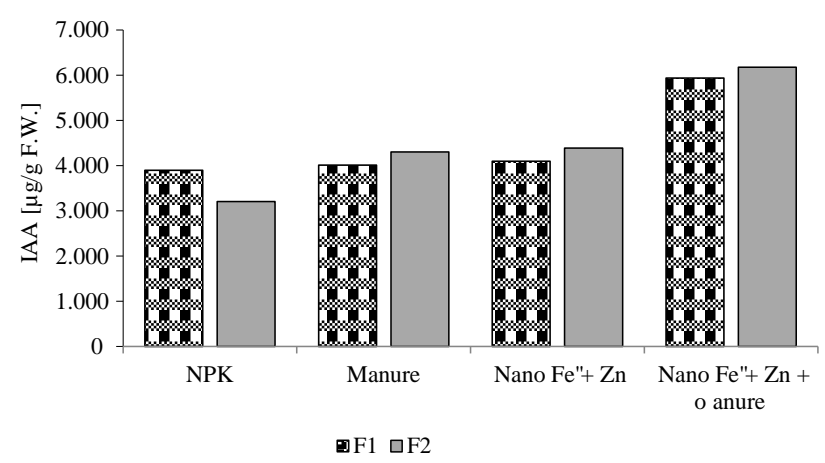

Figure 6. Effect of NPK, manure and nano Fe and Zn on IAA concentration of rocket plants during two seasons F1 - first season; F2 - second season sis and carbohydrate formation (Vitosh et al. 1994). With reference to manure that may contains beneficial microorganisms which increase crop growth by secretion and synthesized phytohormones (Yamada \& Xu 2001).

Concerning ABA content, in the first season, both nano $\mathrm{Fe}+\mathrm{Zn}$ under manure fertiliser treatment and control treatment (NPK) significantly resulted in the lowest $\mathrm{ABA}$ content compared with manure fertiliser alone and nano $\mathrm{Fe}+\mathrm{Zn}$ alone. In contrast, in the second season, it was clear that nano $\mathrm{Fe}+$ $\mathrm{Zn}$ mixed with manure significantly resulted in the lowest $\mathrm{ABA}$ in comparison with all other treatments. The above-mentioned results are in consonance with those obtained by Solimanan and Mahmoud (2013) on Adansonia digitata L. The stimulated effects of mixed treatment may be attributed to the production of hormones like substances from manure fertiliser. As mentioned by Mehnaz et al. (2001), who reported that IAA produced by rhizobacteria as plant growth promoting is believed to increase root growth and root length, resulting in better nutrient uptake present in organic substances.

Marek and Skorupska (2001) provided evidence that Bacillus sp. produced hormones, which effectively reverse a chemical-induced inhibition of stem growth, working together in the presence of organic fertilisers.

\section{CONCLUSIONS}

The achieved results from this investigation are sturdily verify that mixture of nano $\mathrm{Zn}$ and $\mathrm{Fe}$ with manure were boosted growth characters, yield whether seed oil or leaves fresh weight and chemical constituents with concern on main sulphur methyl-thiobutyl-isothiocyanate compound of rocket plant besides antioxidant compounds (ascorbic acid, total phenolics, total flavonoids and carotenoids) as compared to commercial fertilisers NPK. Particularly if we took into consideration that Eruca sativa plant enters variety of high economic pharmaceutical and cosmetics industries. Consequently, it could conclude that nano and organic fertilisers could replace chemical for improving the quality of the produced crops in addition to decreasing the production costs and environmental pollution. 
Acknowledgements. We would like to show our appreciation and express our deepest gratitude towards Cairo University, Faculty of Agriculture, Research Park [FA-CURP] and plant physiology department for samples analyses facilities.

\section{REFERENCES}

ALLOWAY, B.J. 2008. Micronutrients and crop production: An introduction. In ALLOWAY, B.J. (Ed.) Micronutrient deficiencies in global crop production. Netherlands : Springer, pp. 1-39.

AMIRNIA, R. - BAYAT, M. - TAJBAKHSH, M. 2014. Effects of nano fertiliser application and maternal corm weight on flowering at some saffron (Crocus sativus L.) ecotypes. In Turkish Journal of Field Crops, vol. 19, no. 2, pp.158-168.

BADAWI, M.A. - ABOU EL-MAGD, M.M. - HASSAN, H.A - EL-SHAKRY, M.F.Z. 2005. Effect of biofertilization, nitrogen sources, nitrogen levels and their interaction on the vegetative growth, chemical content and oil yield of sweet fennel. In Egyptian Journal of Applied Sciences, vol. 20, no. 28, pp. 567-591.

BALA, N. - DEY, A. - DAS, S. - BASU, R. - NANDY, P. 2014. Effect of hydroxyapatite nanorod on chickpea (Cicer arietinum) plant growth and its possible use as nano-fertilizer. In Iranian Journal of Plant Physiology, vol. 4, no. 3, pp. 1061-1069.

BEHESHTI, A.R. - FARD, B.B. 2010. Dry matter accumulation and remobilization in grain sorghum genotypes (Sorghum bicolorL. Moench) under drought stress. In Australian Journal of Crop Science, vol. 4, no. 3, pp.185-189.

CHAHARDEHI, A.M. - IBRAHIM, D.S. - SULAIMAN, F. 2009. Antioxidant activity and total phenolic content of some medicinal plants in Urticaceae family. In Journal of Applied Biological Sciences, vol. 3, no. 2, pp. 27-31.

DANESHVAR, N. - ABER, S. - SAYED D. - KHATAEE, M.S. - RASOULIFARD, A.R. 2007. Preparation and investigation of photocatalytic properties of $\mathrm{ZnO}$ nanocrystals: effect of operational parameters and kinetic study. In International Journal of Nuclear and Quantum Engineering, vol. 1 , no.1, pp. 24-29.

DENG, X.P. - SHAN, L. - ZHANG, H. - TURNER, N.C. 2004. New directions for a diverse planet. In Proceeding of the $4^{\text {th }}$ International Crop Science Congress, Sep. 26-1st Oct., Brisbane, Australia, p. 26.

DUMAS, Y. - DADOMO, M. - DI LUCCA, G. - GROLIER, P. 2003. Effects of environmental factors and agricultural techniques on antioxidant content of tomatoes. In Journal of the Science of Food and Agriculture, vol. 83, no. 5, pp. 369-382.

DUNCAN, B.D. 1955. Multiple Range and Multiple F-Tests. In Biometrics, vol. 11, pp. 1-42.

EICHERT, T. - KURTZ, A. - STEINER, U. - GOLDBACH, H.E. 2008. Size exclusion limits and lateral heterogeneity of the stomatal foliar uptake pathway for aqueous solutes and water-suspended nanoparticles. In Physiologia Plantarum, vol. 134, no.1, pp. 151-160.

EL-GHAMRY, A.M. - EL-HAMID, A.A. - MOSA, A.A. 2009. Effect of farmyard manure and foliar application of micronutrients on yield characteristics of wheat grown on salt affected soil. In American-Eurasian Journal of Agricultural \& Environmental Sciences, vol. 5, no. 4, pp. 460-465.

EVANS, R.G. - SADLER, E.J. 2008. Methods and technolo- gies to improve efficiency of water use. In Water Resources Research, vol. 44, pp. 1-15.

FAO. 2000. Fertilizers and their use. $4^{\text {th }}$ edition: handbook was prepared originally for use by extension officers working for the FAO Fertilizer Programme. Rome : FAO, p. 34

FAGERIA, N.K. - BALIGAR, V.C. - CLARK, R.B. 2002. Micronutrients in crop production. In Advances in Agronomy, vol. 77 , pp. 185-268.

FAGERIA, N.K. 2012. Role of soil organic matter in maintaining sustainability of cropping systems. In Communications in Soil Science and Plant Analysis, vol. 43, no.16. pp. 2063-2113.

FAIZAN, M. - FARAZ, A. - YUSUF, M. - KHAN, S.T. - HAYAT, S. 2017. Zinc oxide nanoparticle-mediated changes in photosynthetic efficiency and antioxidant system of tomato plants. In Photosynthetica, vol. 55, pp. 1-9.

FALES, H.M. - JAOUNI, T.M. 1973. Simple device for preparing ethereal diazomrthane without restoring to Codisitillation. In Analytical Chemistry, vol. 45, pp. 2302-2303.

GAO, F. - HONG, F. - LIU, C. - ZHENG, L. - SU, M. - WU, X. - YANG, F. - WU, C. - YANG, P. 2006. Mechanism of nano-anatase $\mathrm{TiO}_{2}$ on Promoting Photosynthetic Carbon Reaction of Spinach. In Biological Trace Element Research, vol. 111, no.1, pp. 239-244.

HELRICH, K. 1990. Official methods of analysis. $15^{\text {th }}$ edition, Two volumes. Arlington, USA : Aoac Intl., p. 673.

JACKSON, M.L. 1973. Soil Chemical Analysis. New Delhi : Printice-Hall of India. Privat Limited, New Delhi, Text book, pp. 144-197, 381.

JANMOHAMMADI, M. - AMANZADEH, T. - SABAGHNIA, N. - ION, V. 2016. Effect of nano-silicon foliar application on sunflower growth under organic and inorganic fertilizer regimes. In Botanica Lithuanica, vol. 22, no.1, pp. 53-64.

KARASAHIN, M. 2015. The effects of poultry manure and inorganic fertilizer applications on nitrogen and irrigation water use efficiency in forage corn cultivars. In Journal of Agricultural Faculty of Gaziosmanpasa University, vol. 32, no.1, pp.104-111.

KHOOBCHANDANI, M. - OJESWI,B.K. - GANESH, N. SRIVASTAVA, M.M. - GABBANINI, S. - MATERA,R. - IORI, R. - VALGIMIGLI, L. 2010. Antimicrobial properties and analytical profile of traditional Eruca sativa seed oil: Comparison with various aerial and root plant extracts. In Food Chemistry, vol. 120, no.1, pp. 217-224.

KIM, S.J. - KAWAHARADA, C. - ISHII, G. 2006. Effect of ammonium nitrate nutrient ratio on nitrate and glucosinolate contents of hydroponically-grown salad rocket (Eruca sativa Mill.). In Soil Science Plant Nutrition, vol. 52, no. 3, pp. 387-393.

KINSELLA, J.E. - SHIMP, J.L. - MAI, J. - WEIHRAUCH, J. 1977. Fatty acid content and composition of freshwater finfish. In Journal of the American Oil Chemists Society, vol. 54 , no. 10 , pp. 424-429.

LECLERC, J. - MILLER, M.L. - JOLIET, E. - ROCQUELIN, G. 1991. Vitamin and mineral contents of carrot and celeriac grown under mineral or organic fertilization. In Biological Agriculture \& Horticulture, vol. 7, no. 4, pp. 339-348.

LIU, X. - FENG, Z. - ZHANG, S. - ZHANG, J. - XIAO, Q. - WANG, Y. 2006. Preparation and testing of cementingnano-subnano composites of slow or controlled release of fertilizers. In Agricultural Sciences in China, vol. 9, no. 5, pp. 700-709.

MA, D. - SUN, D. - WANG, C. - DING, H. - QIN, H. - HOU, J. - HUANG, X. - XIE, Y. - GUO,T. 2017. Physiological responses and yield of wheat plants in zinc-mediated alleviation of drought stress. In Frontiers in Plant Science, vol. 
8, pp. 860-887.

MAHMOUD, A.W.M. 2012. Physiological effects of zeolite and organic fertilizers on yarrow plant grown under clean agriculture conditions. In PhD. Thesis, Plant Physiology Department, Fac. Agric., Cairo Univ., Egypt, 297 p.

MAHMOUD, A.W.M. - EL-ATTAR, A.B. - MAHMOUD, A.A. 2017. Economic evaluation of nano and organic fertilisers as an alternative source to chemical fertilisers on Carum carvi L. plant yield and components. In Agriculture (Pol'nohospodárstvo), vol. 63, no.1, pp. 33-49. DOI: 10.1515/agri-2017-0004

MAREK, K.M. - SKORUPSKA, A. 2001. Production of B-group vitamins by plant growth-promoting Pseudomonas fluoresces strain 267 and the importance vitamins in the colonization and nodulation of red clover. In Biology and Fertility of Soils, vol. 33, no. 2, pp. 146-151.

MARSCHNER, P. - RENGEL, Z. 2012. Nutrient availability in soils. In Marschner's Mineral Nutrition of Higher Plants (Third Edition), pp. 315-330.

MARTINEZ-BALLESTRA, M.C. - LOPEZ-PEREZ, L. HERNANDEZ, M. - LOPEZ-BERENGUER, C. - FERNANDEZ-GARCIA, N. - CARVAJAL, M. 2008. Agricultural practices for enhanced human health. In Phytochemistry Reviews, vol. 7, no. 2, pp. 251-260.

MAZAHERINIA, S. - ASTARAEI, A.R. - FOTOVAT, A. MONSHI, A. 2010. Nano iron oxide particles efficiency on $\mathrm{Fe}, \mathrm{Mn}, \mathrm{Zn}$ and $\mathrm{Cu}$ concentrations in wheat plant. In Word Applied Sciences Journal, vol. 7, no. 1, pp. 36-40.

MEHNAZ, S. - MIRZA, M.S. - HAURAT, J. - BALLY, R. -NORMAND, P. - BANO, A. - MALIK, K.A. 2001. Isolation and 16S rRNA sequence analysis of the beneficial bacteria from the rhizosphere of rice. In Canadian journal of microbiology, vol. 47, no. 2, pp.110-117.

MEDA, A. - LAMIEN, C.E. - ROMITO, M. 2005. Determination of the total phenolic, flavonoids and proline contents in Burkina Fasan honey, as well as their radical scavenging activity. In Food Chemistry, vol. 91, p. 571-577.

MOSANNA, R. - BEHROZYAR, E.K. 2015. Morpho- physiological response of maize (Zea mays L.) to zinc nano-chelate foliar and soil application at different growth stages. In Journal on New Biological Reports, vol. 4, no.1, pp. 46-50.

MORAN, R. 1982. Formula for determination of chlorophyll pigments extracted with N.N. dimethyl formamide. In Plant Physiology, vol. 69, pp. 1371-1381.

NADERI, M.R. - DANESH-SHAHRAKI, A. 2013. Nanofertilizers and their roles in sustainable agriculture. In International Journal of Agriculture Crop Science, vol. 5, no. 19 , pp. 2229-32.

NASRI, M. - KHALATBARI, M. - PAKNEJAD, F. 2010. Effect of potassium, iron, and zinc elements in the low-water conditions on quality characteristics of corn seed. In 11 Congress of Iranian Agronomy and Plant Breeding, pp. 94.

PANDEY, S.K. - SINGH, H. 2011. A simple cost-effective method for leaf area estimation. In Journal of Botany, vol. 2011, no. 3, pp. 1-6

PECK, G.M. - ANDREWS, P.K. - REGANOLD, J.P. - FELLMAN, J.K. 2006. Apple orchard productivity and fruit quality under organic, conventional, and integrated management. In Horticultural Science, vol. 41, no. 1, pp. 99-107.

PORTO, R.A. - BONFIM-SILVA, E.M. - SOUZA, D.S.M. CORDOVA, N.R.M. - POLIZEL, A.C. - SILVA, T.J.A. 2013. Potassium fertilization in arugula plants: production and efficiency in water use. In Artigo Científico, vol. 7, no. 1, pp. 28-35.

QU, S. - YANG, H. - REN, D. - KAN, S. - ZOU, G. - LI, D. - LI, M.J. 1999. Magnetite nanoparticles prepared by precipitation from partially reduced ferric chloride aqueous solutions. In Journal of colloid and interface science, vol. 215, no. 1, pp. 190-192.

RAI, M. - RIBEIRO, C. - MATTOSOM, L. - DURAN, N 2015. Nanotechnologies in food and agriculture. Switzerland : Springer International Publisher, p. 347. ISBN 9783-319-14024-7

RALIYA, R. - TARAFDAR, J.C. 2013. ZnO nanoparticle biosynthesis and its effect on phosphorous-mobilizing enzyme secretion and gum contents in cluster bean (Cyamopsistetragonoloba L). In Agricultural Research, vol. 2, no. 1, pp. 48-57.

RALIYA, R. - TARAFDAR, J.C. - BISWAS, P. 2016. Enhancing the mobilization of native phosphorus in mung bean rhizosphere using $\mathrm{ZnO}$ nanoparticles synthesized by fungi. In Journal of agricultural and food chemistry, vol. 64, no. 16, pp. 3111-3118.

RAMESHAIAH, G.N. - JPALLAVI, S. 2015. Nano fertilizers and nano sensors-an attempt for developing smart agriculture. In International Journal of Engineering Research and General Science, vol. 3, no. 1, pp. 314-20.

RICHARDS, L.S. 1954. Diagnosis and improvement of saline and alkaline soils. U.S. Dept. Agric. Handbook No. 60.

RUDRAPPA, L. - PURAKAYASTHA, T.J. - SINGH, D. BHADRARAY, S. 2006. Long-term manuring and fertilization effects on soil organic carbon pools in a Typic Haplustept of semi-arid sub-tropical India. In Soil Tillage Reserche, vol. 88, no. 1, pp. 180-192.

SABAGHNIA, N. - JANMOHAMMADI, M. 2017. Analysis the impact of nano -zinc, nano -iron, and nano -manganese fertilizers. In Pobrane z czasopisma Annales C-Biologia /18:08:13 avaiable at http://biologia.annales.umcs.pl

SARWAR, G. - HUSSAIN, N. - SCHMEISKY, H. - MUHAMMAD, S. - IBRAHIM, M. - SAFDAR, E. 2008. Improvement of soil physical and chemical properties with compost application in rice-wheat cropping system. In Pakistan Journal of Botany, vol. 40, no. 1, pp. 275-282.

SINGLETON, V.L. - ROSSI, J.A. 1965. Colorimetry of total phenolics with phosphomolybdicphosphotungstic acid reagents. In American Journal of Enology and Viticulture, vol. 16 , pp. $144-158$

SOLIMAN, A.SH. - MAHMOUD, A.W.M. 2013. Response of Adansonia digitata to compost and zeolite in replacement of chemical fertilization. In American-Eurasian Journal of Agricultural \& Environmental Sciences, vol. 13, no. 2, pp. 198-206.

SOUSA, C. - PEREIRA, D.M. - PEREIRA, J.A. - BENTO, A. - RODRIGUES, M.A. - GARCÍA, D.S. - VALENTÃO, LOPES, P. - FERRERES, G. - SEABRA, F. - ANDRADE, P.B. 2008. Multivariate analysis of tronchuda cabbage (Brassica oleracea L. var. costata DC) phenolics: influence of fertilizers. In Journal of Agricultural and Food Chemistry, vol. 56, no. 6, pp. 2231-2239.

SUBHAN, A. - KHAN, Q.U. - MANSOOR, M. - KHAN, M.J. 2017. Effect of organic and inorganic fertilizer on the water use efficiency and yield attributes of wheat under heavy textured soil. In Sarhad Journal of Agriculture, vol. 33, no. 4, pp. 582-590.

SUBBAIAH, L.V. - PRASAD, T.N.V.K.V. - KRISHNA, T.G. - SUDHAKAR, P. - REDDY, B.R. - PRADEEP, T. 2016. Novel effects of nanoparticulate delivery of zinc on growth, productivity, and zinc biofortification in maize (Zea mays L.). In Journal of Agriculture and Food Chemistry, vol. 64, no. 19 , pp. 3778-3788.

TARAFDAR, J. - RALIYA, R. - MAHAWAR, H. - RATHORE, I. 2014. Development of zinc nanofertilizer to enhance crop production in pearl millet (Pennisetum americanum). In Agricultural Research, vol. 3, no. 3, pp. 257-262. 
TSAND, M.M.C. - FRUTANI, S.C. 1989. Rapid moisture content determination of macadamia nuts by microwave drying. In Horticulture Science, vol. 24, no. 4, pp. 694-696.

TISDALE, S.L. - NELSON, W.L. 1975. Soil Fertility and Fertilizers. 3rd Edition. New York, USA : Macmillan Publishing, $694 \mathrm{pp}$.

TRINCHERA, A. - REA, E. - RIVERA, C.M. - RINALDI, S. - SEQUI, P. 2008. Use of bio-stimulants to overcome nutrient deficiency. Plant nutrient management under stress conditions. 17th International symposium of CITC, pp. $567-573$.

TRIPATHI, M.K. - CHATURVEDI, S. - SHUKLA, D.K. SAINI, S.K. 2011. Influence of integrated nutrient management on growth, yield and quality of Indian mustard (Brassica juncea L.) in Tarai region of northern India. In Journal of Crop and Weed, vol. 7, no. 2, pp. 104-7.

VITOSH, M.L. - WARNCKE, D.D. - LUCAS, R.E. 1994. Zinc determine of crop and soil, Michigan State University Extension. In Water Air Soil Pollution, vol. 100, pp.133-149.

VOGEL, A.I. 1975. A Text Book of Practical Organic Chemistry. Published by English Language Book society and
Longman Group Limited $3^{\text {rd }}$ Ed., pp. 197-596.

WHITE, A.C. - ROGERS, A. - REES, M. - OSBORNE, C.P, 2016. How can we make plants grow faster? A source-sink perspective on growth rate. In Journal of Experimental Botany, vol. 67, no. 1, pp. 31-45.

YAMADA, K. - XU, H. 2001. Properties and applications of an organic fertilizer inoculated with effective microorganisms. In Journal of Crop Production, vol. 3, no. 1, pp. 255-268.

YANIV, Z. - SCHAFFERMAN, D. - AMAR, Z. 1998. Tradition, uses and biodiversity of rocket (Eruca sativa, Brassicaceae) in Israel. In Economic Botany, vol. 52, no. 4, pp. 394-400

ZAKERIN, H.R. - SHIRANI, A.H. - SEIFZADEH, S. - VALADABADI, S.A. - MOSTASHARI, M.M. 2014. Evaluation the effect of $\mathrm{Zn}$, Fe foliar application and variety on quality and physiological characteristics of canola (Brassica napus L.) under different ranges water deficit stress. In Advances in Environmental Biology, vol. 8, no. 1, pp. 255-260.

Received: January 4, 2018 